\title{
Policies and practices of pastoralism in Europe
}

\author{
Carol Kerven ${ }^{*}$ and Roy Behnke
}

* Correspondence:

carol_kerven@msn.com Odessa Centre, 2 The Ridgeway, Great Wolford, Warks CV36 5NN, UK

\section{Editorial}

The shepherding of livestock on open pastures is an essential marker of pastoralist management. In modern Europe this practice still persists in various truncated forms.

In many parts of the world, government policies undervalue or actively discourage pastoralism, especially mobile pastoralism. Europe is an exception to this trend. Backed by scientific evidence, European Union (EU) policies officially endorse low intensity, transhumant livestock management in Europe as a source of diverse environmental, economic and cultural benefits. Far from seeking to eradicate mobile pastoralism, the European Union explicitly attempts to preserve it, through economic subsidies to livestock farmers, and programmes aimed at marginal grassland areas.

Is there something special about European pastoralism, or have European policy makers simply recognized advantages associated with pastoralism that officials in many other parts of the world have missed?

The answer to this question could, paradoxically, be more important for non-European than European pastoralists. While there may be only a few hundred thousand practicing pastoralists remaining in Europe, elsewhere millions of pastoralists are subjected to national policies which are often inimical to extensive livestock production methods and cultural continuity. As an example of policy alternatives that many other governments have declined to adopt, the unfolding trajectory of European supra-state and national policies towards pastoralism is relevant outside of Europe.

The journal has previously published case studies on transhumant pastoralism in France, Romania and Spain (Biber 2010; Huband et al. 2010; Manzano and Casas 2010). We now present three further case studies from western Europe (Sweden, Italy and Greece), and a summary of how European Commission (EC) programmes within the Common Agricultural Policy (CAP) support extensive and transhumant livestock management in the "less favoured areas" - the highlands and byways of more thinly populated European regions. We also include a report on the transhumant Kurds of eastern Turkey, a nation on the very eastern edge of Europe which may in the future join the EU.

The European Commission considers that the extensive management of livestock on pasture land can assist in halting biodiversity decline, and the Commission promotes this type of land use, which it terms High Nature Value (HNV) farming.

"A characteristic of HNV farming in many regions is a reliance on common grazing lands. Although barely on the radar of many agricultural policy makers, common 
grazing land covers many millions of hectares of European farmland". http://www. efncp.org/high-nature-value-farmland/

"The most widespread type of HNV farmland consists of semi-natural vegetation under low-intensity use for livestock raising. The grazed semi-natural vegetation may be grassland, scrub or woodland, or a combination of different types...Often the semi-natural grazing is not part of the farm holding, but has some other ownership (common land, State land etc.)." http://www.efncp.org/high-nature-valuefarmland/hnv-farming/types/

Nearly one third of all farm land in the EU is classified as HNV (Table 1), while in some countries more than a half of farmland is HNV - including Spain, Italy, Greece and Slovenia. The largest areas of HNV land are in the most wealthy and highly-industrialized European countries of Spain, France, Germany, Italy, and UK. Clearly, economic advancement is not incompatible with preserving ancient land use systems of pasturing livestock extensively.

The pastoral production system in Europe typically depends on transhumance - seasonally moving livestock from one type of pasture to another, and grazing on stateowned land and conservation areas. These pastoralist systems are documented for example in Bulgaria, Germany, Ireland, Wales, Scotland and Sweden, in cases summarized in the European Forum for Nature Conservation and Pastoralism. http://www. efncp.org/

Pastoralism is actively supported in European countries by the EC through funds distributed to farmers through the Common Agricultural Policy (CAP). The various programmes and their intentions are briefly outlined in the paper by Nori and Gemini: "The Common Agricultural Policy vis-à-vis European pastoralists: Principles and practices". Farmers whose management of land and livestock meet certain CAP criteria are eligible for EC payments, through a number of different, sometimes complex and overlapping schemes. A major redirection of EC agricultural policy since 2003 has altered the incentive structure for how land and livestock are managed, as farmers no longer receive subsidy payments per head of animal owned (which prioritised farm output), but can now receive payments according to the category of the land they use and the

Table 1 European Union countries with major areas of High Nature Value (HNV) farmland (Source: Paracchini et al. 2008)

\begin{tabular}{lll}
\hline & Total ha HNV & \% HNV of all farmland \\
\hline Spain & $18,986,960$ & 55.8 \\
\hline France & $7,797,145$ & 22.1 \\
\hline Italy & $6,127,030$ & 33.4 \\
\hline Greece & $5,349,572$ & 58.6 \\
\hline UK & $5,165,466$ & 26.7 \\
\hline Romania & $4,860,372$ & 33.7 \\
\hline Poland & $4,813,243$ & 23.8 \\
\hline Germany & $3,162,699$ & 14.6 \\
\hline Portugal & $2,900,462$ & 57.6 \\
\hline Bulgaria & $2,509,989$ & 37.3 \\
\hline Austria & $2,447,292$ & 68.4 \\
\hline Total EU & $74,659,056$ & 31.9 \\
\hline
\end{tabular}


husbandry methods they practice. These new policies deliberately favour environmental protection. European pastoralists who raise traditional livestock breeds grazing on pastures, and use low levels of inputs, in territories which cannot easily be used for arable farming, are rewarded for income foregone in not converting to more intensive high input farming. As the authors note, for the CAP "public financial support [i.e. derived from European tax revenues] more directly relates to the proper stewardship of land and farmers' practices are remunerated for their capacity to deliver the basic public goods desired by European society". Whether or not one agrees that groups of citizens should be singled out for special treatment through taxpayers' subventions, how the edifice that is the CAP - with its "pillars" and "axes" - works to recompense European pastoralism ought to claim the attention of anyone concerned with the administration of pastoral areas and peoples in other parts of the world.

Three country case studies provide more detailed accounts of how the CAP affects European pastoralists, and whether the CAP meets its goals in practice. In northern Sweden, we find out that a small group of transhumant farmers champion an ancient breed of cattle that ranges freely, grazing on the sub-arctic common land and returning to the farmsteads at night, co-existing with bears and wolves in the mountain forests. In her paper "What is traditional pastoral farming? The politics of heritage and 'real values' in Swedish summer farms (fäbodbruk)", Camilla Eriksson debates the merits of the Swedish government efforts to uphold two goals - preservation of natural and cultural heritage - in dealing with these transhumant farmers, their livestock and land management methods. Under the EC principle of subsidiarity, in which EC member states can implement a more specific programme based on a general EC directive, the Swedish national and local administrations apply various CAP programmes in these pastoral regions of northern Sweden. These programmes have uncovered contradictions between what is defined as "traditional culture" and "environmental protection", and who is empowered to make and act upon these definitions. These activities are not necessarily in harmony - as two examples illustrate. The first is the "traditional breed politics" - summed up by the questions "when is a livestock breed traditional, and what is its purpose?" In the context of the EC CAP distribution of funds, money rests on how these questions are answered. The second example of ambiguities in the application of the broad and undoubtedly well-meant CAP goals is the danger that wolves pose to free-ranging cattle, versus the Swedish state and environmentalists' wish to preserve wolves as part of the forest biodiversity and natural heritage. This is a familiar argument between interest groups in many other pastoral landscapes, such as the American west and the East African savannahs.

The ambiguities resulting from efforts to simultaneously support cultural heritage, traditional practices, economic development, environmental protectionism and panEuropean policies are again apparent in how extensive and transhumant livestock rearing is changing in modern Italy and Greece. The paper by Andrea Pardini and Michele Nori, "Agro-silvo-pastoral systems in Italy: Integration and diversification" details how the balance of forests, crop land and pasture land has altered in the past half century. Livestock rearing has become more intensified and spatially concentrated, and rural outmigration has left large pasture areas abandoned, under-grazed and reverting to forests. Italian laws apply EC CAP policies and funding to encourage livestock farmers to diversify their sources of income. The policy aim is to regain environmental stability 
and retain people in more remote regions. Several innovations are promoted through government programmes - agri-tourism, farm visits to assist mental and physical wellbeing, specialised food products of "local and organic origin", and encouraging re-connections with environmental and cultural heritage through adoption schemes for native trees and wild animals. Here we find the same refrains of "authenticity and nostalgia" referred to by Eriksson in her paper. In Italy, shepherding is increasingly hired out to non-national migrants, and in order to survive, pastoral farms are becoming multifunctional businesses, more integrated into the wider urban economy, but ironically, achieving this through marketing their cultural and environmental heritage.

There are similar patterns to Italy, further east along the Mediterranean basin in the situation of extensive pastoralism in the rocky landscape of Greece's hilly interior mainland and islands. Ioannis Hadjigeorgiou in his paper "Past, present and future of pastoralism in Greece" provides a broad sweep of pastoralism's history over the larger former Greek territory, in which pastoralists often played a central role in politics, agriculture and the military. As in Italy, shepherding has roots in antiquity, and was mentioned in classical Greek and Roman texts. In the more recent past, seasonal transhumance routes were much longer, with shepherds moving livestock through the entire Balkan lands controlled by the Ottoman Empire. With respect to contemporary conditions, the author discusses the profound changes in the ways and places that livestock are reared, involving a reduction or termination of seasonal transhumance, greater dependence on cultivated animal feed under sedentary management, and abandonment of more remote pastoral regions. It does not seem that the new EC CAP environmentally-focussed farming policies have had much impact on Greek livestock farmers, due to the uneven application of EC CAP facilities by local authorities. Of much greater impact are the national social and economic trends such as rural outmigration, rising demand for sheep and goat dairy products (produced under hygienic conditions) and the greater productivity of arable farming which has lowered the cost of livestock feed. There are policy efforts to reverse these trends and encourage more "eco-friendly" techniques, organic products and touristically-appealing pastoral farming. The author points out the serious risks to the cessation of free-range grazing by livestock; the alteration of vegetation dynamics and the invasion of woody species that fed the forest fires that engulfed Greece over several summers and caused immense damage. The role of grazing in reducing the risk of fire provides an additional practical argument for strengthening the pastoral livestock sector in the Mediterranean lands.

In Anatolia, eastern Turkey, Kurdish tribes still undertake seasonal migrations with their flocks of indigenous sheep breeds, living in nomadic tents for some part or sometimes even the entire year. Michaël Thevenin, a mountaineer, has encountered some of the Kurdish tribes en route between their summer and winter pastures, and undertaken to record some of their migration patterns and current situation. His paper "Kurdish transhumance: Pastoral practices in south-east Turkey" offers a rare insight into the continuation of semi-nomadic ways of life on the outskirts of Europe, by the Kurds, a people spread across several adjoining Middle Eastern states. Noting that present-day Kurdish transhumance systems in Turkey are not widely reported, the author describes a number of their annual migratory paths, and the particular reasons why these are followed. Here we encounter "authenticity" and "tradition" apparently preserved without the intervention of national policies or programmes, in contrast to the 
cases met in Sweden, Italy and Greece. The different styles of the nomad tents are closely linked with separate clan identities, but as the author points out, Kurdish pastoralists have also adopted some very modern practices, such as forming commercial livestock marketing corporations and using their tribal affiliations to join into national political parties. The question remains whether and how long the customary annual migrations of the Kurdish clans can carry on into the future, and how these might be affected by EC policies if Turkey joins the European Union.

Competing interests

The authors declare that they have no competing interests.

Received: 3 November 2011 Accepted: 23 November 2011 Published: 23 November 2011

\section{References}

Biber, J-P. 2010. Transhumance in France. Pastoralism 1(1): 91-98.

European Forum on Nature Conservation and Pastoralism. http://www.high-nature-value-farming.eu/. Accessed 3 November 2011.

Huband, S, DI Mccracken and A Mertens. 2010. Long and short-distance transhumant pastoralism in Romania: past and present drivers of change. Pastoralism 1(1): 56-72.

Manzano Baena, P, and R Casas. 2010. Past, present and future of Trashumancia in Spain: nomadism in a developed country. Pastoralism 1(1): 73-90.

Paracchini, ML, Petersen J-E, Hoogeveen Y, Bamps C, Burfield I, and C van Swaay. 2008. High Nature Value Farmland in Europe: An estimate of the distribution patterns on the basis of land cover and biodiversity data. Report EUR 23480 EN For European Commission, Joint Research Centre and Institute for Environment and Sustainability. http://agrienv.jrc.ec. europa.eu/publications/pdfs/HNV_Final_Report.pdf.

\section{Submit your manuscript to a SpringerOpen ${ }^{\odot}$} journal and benefit from:

Convenient online submission

- Rigorous peer review

- Immediate publication on acceptance

- Open access: articles freely available online

- High visibility within the field

- Retaining the copyright to your article

Submit your next manuscript at $>$ springeropen.com 